\title{
The Effect of Selenium and Lycopene on Oxidative Stress in Bone Tissue in Rats Exposed to Cadmium
}

\author{
Tarfa Al Ibrahim1, Hamza Abu Tarboush2 , Ahmad Aljada ${ }^{3}$, Mai Al Mohanna4 \\ ${ }^{1}$ Department of Food Science and Nutrition, Princess Noura Bint Abdulrahman University, Riyadh, KSA \\ ${ }^{2}$ Department of Food Science and Nutrition, King Saud University, Riyadh, KSA \\ ${ }^{3}$ Department of Basic Medical Sciences, King Saud bin Abdulaziz University for Health Sciences \& King Abdullah \\ International Medical Research Center (KAIMRC), Riyadh, KSA \\ ${ }^{4}$ King Faisal Specialist Hospital and Research Centre, Riyadh, KSA \\ Email: t.ibrahim811@gmail.com, ${ }^{*}$ tarboush@ksu.edu.sa, aljada2000@gmail.com, malmohanna@kfshrc.edu.sa
}

Received 5 June 2014; revised 8 July 2014; accepted 20 July 2014

Copyright (C) 2014 by authors and Scientific Research Publishing Inc.

This work is licensed under the Creative Commons Attribution International License (CC BY).

http://creativecommons.org/licenses/by/4.0/

(c) (i) Open Access

\section{Abstract}

This study examined the effect of selenium (Se) or lycopene (Lyc) and their combination on oxidative stress in bone following cadmium (Cd) exposure in vivo. Cd exposure enhanced accumulation of Cd in femur with subsequent increase in LPO and PC and decreased antioxidative enzyme activities in rat femur, along with significant decreases in body and femur bone weights. Subcutaneous (s.c.) injection of Se or Lyc reduced Cd accumulation in bone and increased body and femur weights, when given individually or concomitantly. Antioxidant enzyme activities maintained and/or increased following Se and Lyc supplementation when given individually or concomitantly. However, lycopene dose of $10 \mathrm{mg} / \mathrm{kg}$ of body weight alone or selenium alone provided better protection to bone tissues of rats against oxidative stress compared to treatment with their combination. Selenium and lycopene could be used as a dietary supplement to protect against bone oxidative stress in areas exposed to Cd pollution.

Keywords

Selenium, Oxidative Stress, Lycopene, Cadmium

\section{Introduction}

Industrial development in Saudi Arabia has led to various environmental pollutions especially with heavy metals. Badr et al. [1] indicated that pollution with heavy metals including cadmium increased in Jeddah, Rabeg and

*Corresponding author.

How to cite this paper: Al Ibrahim, T., Tarboush, H.A., Aljada, A. and Al Mohanna, M. (2014) The Effect of Selenium and Lycopene on Oxidative Stress in Bone Tissue in Rats Exposed to Cadmium. Food and Nutrition Sciences, 5, 1420-1429. http://dx.doi.org/10.4236/fns.2014.514155 
Yunbou (West of Saudi Arabia). Moreover, pollution of rice consumed in Saudi Arabia has increased due to contamination by cadmium [2]. Study conducted by Al-Farraj and Al-Wabel [3] confirmed the increase in cadmium contamination in soils of Saudi Arabia. They pointed out that contamination of soil with cadmium in Mahd Alzahab (South East of the city of Madinah, Saudi Arabia) comprised 88\% of the total heavy metals contamination.

Cadmium is dangerous to humans since it affects many organs in human body particularly bone [4]. Cadmium may affect bone tissue through disorders due to oxidative/antioxidative balance which leads to oxidative stress and antioxidants deficiency can have a negative impact on bone health, whereas antioxidants may prevent the disorders impacted by the oxidative damage induced by reactive oxygen species (ROS) in the bone tissue [5]. Daily selenium intake of $77.8 \%$ breast-fed infants in Saudi Arabia is low [6] compared to US recommendation [7]. Selenium is a known antioxidant essential element [8]. Lycopene is also an antioxidant which is found to decrease the risk of bone resorption markers [9]. The combination of selenium and lycopene could have even more effects compared to the effects of each one alone. Therefore, the aim of this research was to evaluate the effect of selenium and lycopene alone or in combination on oxidative stress in bone tissue in rats exposed to cadmium.

\section{Materials and Methods}

\subsection{Animals and Experimental Protocol}

Fifty-four Sprague Dawley male rats (7 weeks old) with an approximate weight of 200 - 250 gm. were utilised in this study. The rodents were housed at King Faisal Specialist Hospital in plastic cages in a temperature-controlled $\left(21^{\circ} \mathrm{C} \pm 2^{\circ} \mathrm{C}\right)$ room with $12 \mathrm{~h}$ light $/ 12 \mathrm{~h}$ dark cycle. A water and pellet laboratory animal diet was available ad libitum (Table 1). Initial weights and weekly gain in weight of rats were recorded. The rats were randomly divided into six groups with nine rats per group. Three groups were designated as "control groups" and 3 were designated "treated groups". The control groups were subcutaneously (s.c.) injected with saline solution or olive or Cd ( $3 \mathrm{mg} / \mathrm{kg}$ body weight), respectively. The first treated group was s.c. injected with Se (selenium sodium selenite $\left.99 \%\left(\mathrm{Na}_{2} \mathrm{SeO}_{3}\right)\right)(3.5 \mathrm{mg} / \mathrm{kg})+$ (s.c.) injected with $\mathrm{Cd}(3 \mathrm{mg} / \mathrm{kg}$ body weight), while the second group was s.c. injected with $10 \mathrm{mg} \mathrm{Lyc} / \mathrm{kg}+$ (s.c.) injected with Cd (3 mg/kg body weight). The third group was s.c. injected with Se (3.5 mg/kg) and $10 \mathrm{mg} \mathrm{Lyc/kg} \mathrm{+} \mathrm{s.c.} \mathrm{injected} \mathrm{with} \mathrm{Cd} \mathrm{(3} \mathrm{mg/kg} \mathrm{body} \mathrm{weight).}$ The injection of Se or Lyc was $1 \mathrm{~h}$ prior to Cd injection. Administration of all doses was daily for the first four weeks; however, due to changes in the skin of the treated rats, doses were given for four days weekly for the remaining eight weeks of the study. Guidelines for animal care approved by the ethics committee of KFSHRS were followed (RAC\# 2110019). All animal experiments were maintained in accordance with guidelines for the care and use of laboratory animals of the research centre at King Faisal Specialist Hospital \& Research Centre, Riyadh, KSA. Cd and Se were prepared by dissolving in sodium chloride (saline, $0.9 \% \mathrm{NaCl}$ ). Lyc was dissolved in olive oil before it was s.c. injected. The rats were euthanized at the end of the twelfth week using ketamine $(80 \mathrm{mg} / \mathrm{kg}$ ) and xylazine $(5 \mathrm{mg} / \mathrm{kg})$ through intramuscular injection. The right femurs were dissected out and the surrounding muscles and tissues were removed [10]. All femur samples were weighed and preserved at $-80^{\circ} \mathrm{C}$.

Table 1. Diet composition*

\begin{tabular}{ccc}
\hline Dietary Components & \% of Laboratory Animal Diet (Net Weight $50 \mathrm{~kg})$ \\
\hline Protein & $20 \%$ \\
Fat & Fiber & $4 \%$ \\
Energy & $3.05 \%$ \\
Calcium & $2770 \mathrm{kcal} / \mathrm{kg}$ \\
Phosphorus & $0 \%$ \\
Vitamin A & $0.60 \%$ \\
Vitamin D & $20 \mu \mathrm{g}$ \\
\hline
\end{tabular}

\footnotetext{
*Silos and flour mills organization, KSA.
} 


\subsection{Preparation of Homogenised Bone Tissue Samples}

Known weight slice of femurs were washed out in ice-cold saline $(0.9 \% \mathrm{NaCl})$ to eliminate the bone marrow. The homogenised samples were prepared as previously described [11] [12]. RIPA buffer, as opposed to potassium phosphate buffer, was used to obtain a $20 \%$ bone concentration, with an addition of butyl-hydroxytoluene (BHT; Sigma-Aldrich) and protease inhibitors. The homogenates were centrifuged at 10,000 $\times \mathrm{g}$ for $20 \mathrm{~min}$ at $4^{\circ} \mathrm{C}$ and the supernatants were collected and used for the measurements of oxidative stress indices and antioxidant status. Analysis was performed in duplicate for all the analyses measured in this study.

\subsection{Measurement of Cd Concentration}

Slices of the femurs were dried at $64^{\circ} \mathrm{C}$ for 48 hours, and then digested and pulverised in nitric acid, according to Kingston and Walter [13]. Cd concentration levels were then determined with MSnductively ICP coupleads plasma mass spectrometry (ICP-MS).

\subsection{Measurement of Antioxidants and Oxidation Levels in Bone Tissue}

\subsubsection{Catalase (CAT) Activity}

CAT enzyme activity was assayed according to the method of Aebi [14] using ready-made enzymatic preparations supplied by Sigma Aldrich, USA. The CAT enzyme activity was further determined by measuring the rate of transformation of hydrogen peroxide to water by employing an optical spectrometer (Absorbance Microplate Reader SpectraMax Plus 384, Molecular California Devices, USA) at a wavelength of $520 \mathrm{~nm}$.

\subsubsection{Cu-Zn Superoxide Dismutase (Cu-Zn SOD)}

$\mathrm{Cu}-\mathrm{Zn}$ SOD activity was determined according to the method of Kakkar et al. [15] by applying ready-made enzymatic solutions supplied by Cayman Chemical Company (Anne Arbour, MI, USA). An optical spectrometer was used for the analysis at a wavelength of $450 \mathrm{~nm}$.

\subsubsection{Cellular Glutathione Peroxidase (GPx)}

Cellular GPx was determined using the method described by Rotruck et al. [16] using pre-prepared enzymatic solutions (BioxytechGPx kit 340) supplied by Oix Research Chemical Company, USA. An optical spectrometer was used for the analysis at a wavelength of $340 \mathrm{~nm}$.

\subsection{Lipid Peroxidation (LPO)}

Malondialdehyde and 4-hydroxyalkenal were used as indicators of oxidation of polyunsaturated fatty acids. The estimated fat oxidation was assayed by colouration of pre-prepared enzymatic solutions supplied by Oix Chemical CO, USA (Biotech LPO-586 kit), and using a spectrometer at a wavelength of $586 \mathrm{~nm}$ [17].

\subsection{Protein Carbonyl Content (PC)}

PC were estimated as previously described [18] using the pre-prepared enzymatic solution (Protein Carbonyl Flurometric Assay Kit, Cyman Chemical Company) and a Spectral Scanning Microplate Reader (Thermo-Labsystems Varioskan Flash Multimode, Thermo Fisher Scientific Inc., USA).

\subsection{Statistical Analysis}

Data were analysed using one-way ANOVA and SAS program. Duncan's multiple range test was used to analyse data and to determine significant differences among treatment means. Values were considered statistically significant when $\mathrm{P}<0.05$. We determined that a sample size of 8 would detect a difference in bone weight following Cd administration of $=25 \%$ at $\mathrm{P}=0.05$ with $80 \%$ power. However, a sample size of $\mathrm{n}=9$ per group was used to account for any animal loss or bad sample collection.

\section{Results}

\subsection{Effects of Cadmium, Selenium and Lycopene on Body Weight}

The effect of cadmium on the body weight of rats is shown in Table 2 . The body weight of the cadmium treated 
Table 2. Body weight and body weight gain in control saline $\mathrm{C}$ and rats exposed for 12 weeks to cadmium (Cd), cadmium + selenium $(\mathrm{Cd}+\mathrm{Se})$, cadmium + lycopene (Cd + Lyc), cadmium + lycopene + Se (Cd + Lyc + Se).

\begin{tabular}{cccccc}
\hline & C & Cd & Cd + Se & Cd + Lyc & Cd + Lyc + Se \\
\hline Initial body weight (g) & $240 \pm 63^{\mathrm{A}}$ & $237 \pm 4.5^{\mathrm{A}}$ & $242 \pm 3.3^{\mathrm{A}}$ & $235 \pm 3.8^{\mathrm{A}}$ & $238 \pm 3.0^{\mathrm{A}}$ \\
Final body weight (g) & $349 \pm 64^{\mathrm{B}}$ & $265 \pm 12.2^{\mathrm{A}}$ & $285 \pm 11^{\mathrm{B}}$ & $323 \pm 4.0^{\mathrm{B}}$ & $294.8 \pm 5.4^{\mathrm{B}}$ \\
\% Body weight gain (12 weeks) & $46 \pm 2.9^{\mathrm{a}}$ & $9 \pm 1.3^{\mathrm{d}}$ & $24 \pm 3.6^{\mathrm{C}}$ & $38 \pm 1.9^{\mathrm{b}}$ & $24 \pm 2.01^{\mathrm{C}}$ \\
\hline
\end{tabular}

Results are presented as mean $\pm \mathrm{SE}$; Means not sharing a common superscript a big letters in column are significantly different at $\mathrm{P}<0.05$; Means not sharing a common superscript a small letters in raw are significantly different at $\mathrm{P}<0.05$ as assessed by Duncan’s multiple-range test.

rats increased slightly (9\%) but the body weight of the other two control treated rats increased significantly $(\mathrm{P} \leq$ 0.05) at the end of the experimental period. Chen et al. [19] indicated a decrease in the body weight of male Sprague Dawley rats treated with cadmium at a dose of $1.5 \mathrm{mg} / \mathrm{kg}$ body weight. Rabbits treated with oral dose of $5 \mathrm{mg}$ cadmium/kg b.w. showed significant $(\mathrm{P} \leq 0.05)$ decrease in body weight after four months when compared to the control group. On the other hand, treatment of the male rats with selenium and lycopene either alone or in combination caused statistically $(\mathrm{P} \leq 0.05)$ increase in body weight (Table 2). The increase in body weight was higher in the rats treated with $10 \mathrm{mg}$ lycopene $/ \mathrm{kg}$ b.w. than the other treated groups as well as the cadmium treated one. These results agree with results reported by Messaoudi et al. [20], who reported that selenium increased the body weight of Wistar rats exposed to cadmium. The increase in body weight of rats in this study also agree with the finding of Rencuzogullari and Erdogan [21], who showed an increase in the body weight of rats exposed orally to cadmium and given a dose of $10 \mathrm{mg}$ lycopene $/ \mathrm{kg}$ b.w.

\subsection{Effects of Selenium and Lycopene on Cadmium Concentration in Femoral Bone Tissue and on Its Weight}

Injection of the rats with dose of $3 \mathrm{mg}$ cadmium/hg b.w. for 12 weeks caused accumulation of this element in femoral bone tissue. Cadmium concentration increased significantly $(\mathrm{P} \leq 0.05)$ in these rats (about 574 folds) compared to the other two control groups given saline solution and olive oil, respectively (Table 3). Results of this study agree with the finding of Brozoska et al. [5], who indicated similar increase in bone tissue of rats given orally a dose of $2.5 \mathrm{mg}$ cadmium $/ \mathrm{kg}$ b.w. for six months.

A significant $(\mathrm{P} \leq 0.05)$ decrease in cadmium concentration in femoral bone tissue was observed in rats administered selenium and lycopene either alone or in combination. However, selenium and lycopene alone had the greatest effect than their combinations. Data are lacking in the literature (to the best of our knowledge) on the effects of selenium and lycopene on cadmium concentration on bone tissue and this study report such data for the first time. Due to the lack of such data comparison in this study was made with studies evaluated their effects on other tissues. Brzoska et al. [10] studied the effect of zinc ( $60 \mathrm{mg} / \mathrm{L}$ of drinking water) on cadmium concentration of the femoral bone tissue and found that zinc reduced the cadmium concentration by $18 \%$. Alhazza's study [22] also indicated a reduction in cadmium concentration on the testes of rats exposed to cadmium and injected by selenium $(0.35 \mathrm{mg} / \mathrm{kg}$ b.w.).

Femoral bone weight decreased significantly $(\mathrm{P} \leq 0.05)$ in the group of rats exposed to cadmium compared to control one (Table 3). Selenium and lycopene either alone or in combination reversed the effect of cadmium on bone weight. Selenium and lycopene (10 gm/kg b.w.) alone and selenium plus lycopene (1 $5 \mathrm{gm} / \mathrm{kg}$ b.w.) had the greatest effect in reversing the loss of bone weight; however, full attainment of bone weight was not accomplished by the use of selenium and lycopene either alone or in combination. Brzoska et al. [10] indicated that zinc given to rats exposed to cadmium increased bone weight after 12 months of the treatment. Selenium with vitamin $\mathrm{E}$ or $\mathrm{C}$ improved also skeletal changes of the bone of the femoral osteoporotic rabbits [23].

\subsection{Effects of Selenium and Lycopene on Oxidative Enzymes}

The effects of selenium and lycopene either alone or in combination on CAT of male rats treated with cadmium are shown in Table 4. Cadmium administration for 12 weeks reduced CAT activity in rats bone tissue by $60 \%$ (from 30 to $18 \mu \mathrm{mole} / \mathrm{min} / \mathrm{mg}$ of protein). Selenium and lycopene alone preserved CAT activity completely, whereas their combinations preserved most of this activity (Table 4). Study by Messaoudi et al. [24] revealed that zinc and selenium either alone or in combination preserved CAT activity in the red blood cells of rats ex- 
Table 3. Cdmium concentration ( Cd conse) in femoral bone and femoral bone weight of control saline $\mathrm{C}$ and rats exposed for 12 weeks to cadmium $(\mathrm{Cd})$, cadmium + selenium $(\mathrm{Cd}+\mathrm{Se})$, cadmium + lycopene $(\mathrm{Cd}+\mathrm{Lyc})$, cadmium + lycopene + Se $(\mathrm{Cd}+\mathrm{Lyc}+\mathrm{Se})$.

\begin{tabular}{cccccc}
\hline & C & Cd & Cd + Se & Cd + Lyc & Cd + Lyc + Se \\
\hline Cd conse mg/kg dry weight & $13.3 \pm 1.8^{\mathrm{e}}$ & $7652 \pm 254^{\mathrm{a}}$ & $4392 \pm 123^{\mathrm{c}}$ & $4565 \pm 275^{\mathrm{c}}$ & $5798 \pm 229^{\mathrm{b}}$ \\
Femoral bone weight gm & $1.02 \pm 0.023^{\mathrm{a}}$ & $0.69 \pm 0.014^{\mathrm{d}}$ & $0.95 \pm 0.020^{\mathrm{b}}$ & $0.90 \pm 0.020^{\mathrm{b}}$ & $0.81 \pm 0.021^{\mathrm{c}}$ \\
\hline
\end{tabular}

Results are presented as mean $\pm \mathrm{SE}$; Means not sharing a common superscript letters in a row are significantly different at $\mathrm{P}<0.05$, as assessed by Duncan's multiple-range test.

Table 4. Catalase (CAT), cupper zinc superoxide dismutase (Cu-Zn SOD) activities, and glutathion peroxidase (GPx) in bone tissue of control saline $\mathrm{C}$ and rats exposed for 12 weeks to cadmium (Cd) cadmium + selenium (Cd + Se), cadmium + lycopene, cadmium + lycopene + Se $(\mathrm{Cd}+\mathrm{Lyc}+\mathrm{Se})$.

\begin{tabular}{cccccc}
\hline Antioxidant activity & C & Cd & Cd + Se & Cd + Lyc & Cd + Lyc + Se \\
\hline CAT Umol/min/mg & $29.6 \pm 1.40^{\mathrm{a}}$ & $19 \pm 0.88^{\mathrm{c}}$ & $30 \pm 1.13^{\mathrm{a}}$ & $30.3 \pm 0.73^{\mathrm{a}}$ & $22.3 \pm 0.70^{\mathrm{b}}$ \\
Cu-Zn SOD U/mg & $0.28 \pm 0.01^{\mathrm{a}}$ & $0.20 \pm 0.02^{\mathrm{b}}$ & $0.32 \pm 0.20^{\mathrm{a}}$ & $0.29 \pm 0.02^{\mathrm{a}}$ & $0.31 \pm 0.01^{\mathrm{a}}$ \\
GPx mu/mg protein & $4.11 \pm 0.3^{\mathrm{a}}$ & $1.9 \pm 0.1^{\mathrm{b}}$ & $4.5 \pm 0.15^{\mathrm{a}}$ & $4.4 \pm 0.31^{\mathrm{a}}$ & $4.9 \pm 0.35^{\mathrm{a}}$ \\
\hline
\end{tabular}

Results are presented as mean $\pm \mathrm{SE}$; Means not sharing a common superscript letters in a row are significantly different at $\mathrm{P}<0.05$, as assessed by Duncan's multiple-range test.

posed to cadmium but the effect of the combination of these two elements was less than that observed with either of them alone. On the other hand, El Heni et al. [25] found that exposure to cadmium caused a decrease of $58.5 \%$ in CAT activity in the liver of rats; however, selenium and lycopene neither alone nor in combinations had significant effects in the activity of this enzyme.

Treatment of male rats with cadmium also reduced significantly $(\mathrm{P} \leq 0.05)$ the activity of SOD in bone tissue, whereas the treatment of these rats with selenium and lycopene either alone or in combination increased significantly $(\mathrm{P} \leq 0.05)$ the activity of this enzyme (Table 4). These results do not agree with the findings of El Heni et al. [25], who stated that selenium had no effect in SOD activity of rats exposed to cadmium. However, these researchers used low dose of selenium ( $0.1 \mathrm{mg} / \mathrm{L}$ of drinking water). Moreover, selenium was given orally in their study.

GPx activity also reduced significantly $(\mathrm{P} \leq 0.05)$ in the bone tissue of rats treated with cadmium and treatments with selenium and lycopene either alone or in combination increased significantly $(\mathrm{P} \leq 0.05)$ the activity of this enzyme (Table 4). Despite the beneficial effects of the all treatment with lycopene and selenium in increasing the activity of GPx, it seems that combination of both of them had higher but not significant affect compared to the effect of each of them alone (Table 4). Moreover, increasing the dose of lycopene to $15 \mathrm{mg} / \mathrm{kg}$ b. w. had no extra beneficial effect on the activity of antioxidant enzymes.

Ognjanovic et al. [26] studied the effect of selenium in the kidney and liver of Wistar rats exposed to cadmium and found that selenium increased significantly $(\mathrm{P} \leq 0.05)$ the activity of GPx in these two tissues.

\subsection{Effects of Selenium and Lycopene on Oxidative Status}

Measuring the activity of antioxidant enzymes as well as indicators of oxidative stress such as Cu-Zn SOD/GPx, malondialdehyde and protein carbonyl concentration are important to know the balance between the first and the second stage of the function of antioxidant enzymes [27]. This means the balance between ROS production and their destruction [28].

Lipid peroxidation was increased significantly $(\mathrm{P} \leq 0.05)$ by $79 \%$ in rats exposed to cadmium compared to rats in the control group; however, both selenium and lycopene either alone or in combination prevented the effect of cadmium and the lipid peroxidation level in the treated rats maintained to its normal level as in the control group (Table 5). This result agrees with the finding of several researchers [5] [21] [29].

Cadmium not only oxidized lipid but also protein and this is indicated by the increase in protein carbonyl concentration in bone tissue of rats exposed to this element (Table 5). Such affect indicates the breakdown of protein in bone especially collagen [5]. Again selenium and lycopene either alone or in combination prevented such effect; however, selenium and lycopene $(10 \mathrm{mg} / \mathrm{kg}$ b.w.) had the greatest effect compared to the other treatments. These results agree with the finding of Brzoska et al. [5]. 
Table 5. Malondialdehyde (MDA), protein carponyl (PC) concentration in bone tissue of control saline C and rats exposed for 12 weeks to cadmium (Cd) cadmium + selenium $(\mathrm{Cd}+\mathrm{Se})$, cadmium + lycopene of body weight (Cd + Lyc), cadmium + lycopene of body weight.

\begin{tabular}{cccccc}
\hline Oxidative status & C & Cd & Cd + Se & Cd + Lyc & Cd + Lyc + Se \\
\hline LPO $\mu \mathrm{m} /$ mg protein & $0.24 \pm 0.01^{\mathrm{b}}$ & $0.43 \pm 0.02^{\mathrm{a}}$ & $0.21 \pm 0.01^{\mathrm{b}}$ & $0.25 \pm 0.013^{\mathrm{b}}$ & $0.22 \pm 0.02^{\mathrm{b}}$ \\
PC nmol/mg protein & $1.6 \pm 0.14^{\mathrm{c}}$ & $2.9 \pm 0.23^{\mathrm{a}}$ & $1.6 \pm 0.12^{\mathrm{c}}$ & $1.3 \pm 0.13^{\mathrm{c}}$ & $2.2 \pm 0.20^{\mathrm{b}}$ \\
\hline
\end{tabular}

Results are presented as mean $\pm \mathrm{SE}$; Means not sharing a common superscript letters in a row are significantly different at $\mathrm{P}<0.05$, as assessed by Duncan's multiple-range test.

\section{Discussions}

$\mathrm{Cd}$ is an environmental pollutant that causes harm to the overall health of human beings. It adversely affects many of the body's tissues, including bone [30]-[32]. The importance of nutritional supplements such as phytochemicals on lowering the harmful effects of Cd on the liver and kidney had been reported [29] [33]. These studies are consistent with the research of Brzoska et al. [5], who concluded that oxidative stress in bone tissue is mainly from Cd exposure and may be responsible for the increase in the amount of people afflicted with bone diseases. Therefore, the aim of this study was to find ways to reduce the oxidative stress levels in bone tissue resulting from Cd exposure; specifically, to study the individual and concomitant effects of Se and Lyc on oxidative stress levels in the bone tissue of laboratory rats that had been exposed to Cd.

The measurement of body weight and the rate of weight gain are important in toxicological studies [34], as they are considered indicators of the extent of deterioration of health. A decrease in these factors is also an indicator of the deficiency in the biological processes in the body [35]. In the present study, exposure to Cd did not lead to a significant increase in body weight gain after 12 weeks from the commencement of the study. This indicates a disruption in the growth of the Cd-exposed rats. These results are consistent with the findings of Chen et al. [19], which indicated a decrease in the body weight of Sprague Dawley rats that were subcutaneously injected with a dosage of $5 \mathrm{mg} / \mathrm{kg}$ of Cd. This study also confirms the findings of Yousef et al. which demonstrated a significant reduction in the body weight of laboratory rabbits that were administered a dosage of 5 $\mathrm{mg} / \mathrm{kg}$ of oral Cd for one month [35].

The reduction in body weight in the Cd-treated group observed could be due to a lack of appetite caused by the high dosage levels. However, the findings could also be attributed to the impact that $\mathrm{Cd}$ exposure had on weight of femurs and other tissues [10] [36] [37]. Interestingly, the reduction in the weight of bone tissue has been associated with $\mathrm{Cd}$ as a result of its effect on several body mechanisms resulting in the generation of free radicals [38]. For this reason, treatment with Se and Lyc, when administered separately or concomitantly, decreased the oxidative stress and enhanced or maintained antioxidant enzyme activities in the Cd treated rats, thus improving rat food palatability, food intake and (eventually) their body weight gain (Table 2).

The impact of Cd on bone tissue is dependent on the time of exposure as well as the age of the animal. The present study demonstrated that exposure of rats to $\mathrm{Cd}$ with an age from seven weeks to five months led to the deposition of high concentrations of Cd in the femur. Brzoska et al. [39] found that exposure to Cd increased its concentration levels in the bone only during the most intensive phase of skeletal growth, that is, up to the 4th month of the animal's life. These results are consistent with other studies which demonstrated higher concentrations of Cd were found in the bones of younger rats than in older ones [40] [41]. This highlights the seriousness of exposure to $\mathrm{Cd}$ at an early age, which is an important stage in the development of bone. Exposure to Cd may impede bone development, causing damage with advancing age. One of the possible reasons for the increased $\mathrm{Cd}$ concentration in bone could be attributed to its interference in the formation of hydroxyapatite $\left(\mathrm{Ca}_{10}\left(\mathrm{PO}_{4}\right)_{6}(\mathrm{OH})_{2}\right)$ which is responsible for the strengthening of the bone tissue, by replacing calcium ions with Cd ions [42]. A link may exist between $\mathrm{Cd}$ and various important proteins in the body in that Cd plays a role in raising the protein concentration of bone tissue. Cd binds to ions that compete with existing thiols to bind with some proteins. When the synthesis of these proteins decreased, the free Cd ions in tissue increased, and started to affect bones and other defense systems in the body [43] [44]. Thus, the increase in ions may be the result of the high concentration of $\mathrm{Cd}$ in the bone tissue. Therefore, Se and Lyc, either separately or concomitantly, played a significant role in reducing the rate of deposition of Cd (Table 3). Furthermore, these antioxidants may contribute to the reduction of Cd ions that bond with important bone components. Bone tissue has defense mechanisms that protect it from the effect of reactive oxygen species (ROS). These defense mechanisms include 
antioxidant enzymes such as CAT, SOD, and GPx. GPx represents the body's main defense system that activates cellular antioxidant enzymes in the bone tissue. It is responsible for restricting LPO, and interacts with CAT in converting hydrogen peroxide $\left(\mathrm{H}_{2} \mathrm{O}_{2}\right)$ to oxygen $\left(\mathrm{O}_{2}\right)$, whereas SOD is accountable for converting $\mathrm{O}_{2} \bullet$ to $\mathrm{O}_{2}$ and $\mathrm{H}_{2} \mathrm{O}_{2}$ [45].

This study showed an inverse relationship between antioxidant enzyme activities and Cd concentrations in femoral tissue (Table 4). The significant decline in antioxidant enzymes (CAT, Cu-ZnSOD, and GPx) could be due to $\mathrm{Cd}$ bonding with enzymes that contain -SH- functional groups, which are meant to defend tissues leading to reduced activity [46]. This could also be through another mechanism resulting from the impedance of Cd activity by replacing the activity of beneficial substances [47]. Another possibility is that Cd depleted the vital elements necessary for the functioning of these enzymes, such as Se, zinc, copper, manganese and iron. CAT contains iron in its active site [45]. Cd may play a role in decreasing iron levels and, as a result, decreased CAT activity. The possibility that $\mathrm{Cd}$ may led to a lack of nutrients such as zinc and copper, which are fundamentals to the formation of SOD, should also be considered [45]. Brzoska et al. indicated that medium and high exposure to Cd reduces the bone tissue's content of zinc, copper and iron [5] [10]. Se also had a positive impact on the activity of Cu-Zn SOD [48]. Therefore, the inhibition of the activity of this enzyme in rats that were given Cd may indicate that the Cd not only caused an imbalance of Se, which is important for this enzyme, but inhibition of its activity. It could also be due to the accumulation of $\mathrm{Cd}$ in bone tissue, where it competes with zinc which is essential to the formation of Zn-Cu SOD [49]. Thus, the decline in the activity of GPx may result from the high concentrations of $\mathrm{Cd}$ in the bone tissue and, as a result, this could be the cause of the depletion of Se which is essential for GPx synthesis [45].

The results of this study also showed that Se and Lyc, individually or concomitantly, had a role in the increase in the activity of antioxidant enzymes in the femoral tissue of rats. This may explain the role of each in reducing the concentration of $\mathrm{Cd}$ in bone tissue. On the other hand, administration of Se and Lyc alone maintained a normal level of CAT activity compared to the other combination group. This may be the reason why these two groups showed more reduction in $\mathrm{Cd}$ concentrations in bone tissue compared to the other treated groups. Se maintained the activity of Cu-Zn SOD and GPx by binding directly with Cd and converting it to an inactive complex compound called Cd complex selenide [50]. Another possibility is that it reduced the Cd link in the active site of these enzymes and weakens their activities. The function of Se is to protect bone tissue from oxidation by protecting antioxidant enzymes. This decreases their vulnerability to $\mathrm{Cd}$ and stops the depletion of the elements necessary to build the active site for these enzymes [45]. Se also plays an important role in building seleno-proteins like GPx [51]. The role of Se in increasing GPx activity in the bone tissue that protects DNA from oxidation was evident in this study.

This study also highlighted the role of Lyc, either alone or in combination with Se, in increasing antioxidant enzyme activities and suggests the possibility of Lyc being an antioxidant compound which protects tissues from the effects of free radicals. Additionally, by reducing the concentration of $\mathrm{Cd}$ in bone tissue, it may reduce tissue damage and the loss of the elements necessary for the formation of antioxidant enzymes.

In addition, Cd treatment led to an increase in LPO in femur bone tissue (Table 5). This could be attributed to the role of $\mathrm{Cd}$ in decreasing the activity of antioxidant enzymes in the tissue responsible for scavenging free radicals. The continued presence of free radicals may be the reason for the oxidation of lipids in the cell walls [52]. The results of this study are consistent with previous results showing that the decline in the activity of GPx was followed by a significant rise in LPO [52]. This supports the role of Se and Lyc in reducing LPO by increasing the activity of GPx and thioredoxin reductase, both of which are important enzymes for the elimination of LPO [29] [51]. Supplementation with Se and Lyc prevented bone lipid from oxidative damage, possibly as a result of their role in maintaining the activity of antioxidant enzymes. This either indicates a reduction in hydrogen peroxide concentration, or that the enzymes became efficient in reducing ROS and, thus, lowering the concentration of LPO. Cd treatment not only led to lipid oxidation, but also to the oxidation of proteins (Table 5). A significant increase was observed in PC concentration in the bone tissue of the Cd treated group. This indicates destruction of the proteins that are present in femoral tissue including collagen [5]. The low PC concentrations in the femoral of rats receiving Se or Lyc could be as a result of their role in maintaining the CAT activity (Table 4) and decreasing Cd accumulation in the femoral tissue (Table 3).

\section{Conclusion}

This study demonstrated that Se and Lyc supplementation reduced Cd concentrations in femoral tissue and also 
increased or maintained the antioxidant enzyme activities by reducing bone oxidative stress. Se and Lyc could be sufficient to reduce the toxicity of $\mathrm{Cd}$ in areas exposed to Cd pollution and could be recommended as a dietary supplement to protect against bone oxidative stress. Further studies are needed to confirm the protective effect of bone tissues by Se and Lyc.

\section{Acknowledgements}

This work was supported by King Abdulaziz City for Science and Technology and King Faisal Specialist Hospital and Research Centre.

\section{References}

[1] Badr, N.B.E., El-Fiky, A.A., Mostafa, A.R. and Al-Mur, B.A. (2009) Metal Pollution Recordsincore Sediments of Some Red Sea Coastal Areas, Kingdom of Saudi Arabia. Environmental Monitoring and Assessment, 155, 509-526. http://dx.doi.org/10.1007/s10661-008-0452-x

[2] Al-Saleh, I. and Shinwari, N. (2001) Report on the Levels of Cadmium, Lead, and Mercury in Imported Rice Grain Samples. Biology of Trace Elements Research, 83, 91-96. http://dx.doi.org/10.1385/BTER:83:1:91

[3] Al-Farraj, A.S. and Al-Wabel, M.I. (2007) Evaluation of Soil Pollution around Mahad AD’ Dahab Mine. Journal of the Saudi Society for Agricultural Sciences, 6, 89-106.

[4] Satarug, S., Baker, J.R., Urbenjapol, S., Haswell-Elkins, M., Reilly, P.E., Williams, D.J. and Moore, M.R. (2003) A Global Perspective on Cadmium Pollution and Toxicity in Non-Occupationally Exposed Population. Toxicology Letters, 137, 65-83. http://dx.doi.org/10.1016/S0378-4274(02)00381-8

[5] Brzoska, M.M., Rogalska, J. and Kupraszewicz, E. (2011) The Involvement of Oxidative Stress in the Mechanisms of Damaging Cadmium Action in Bone Tissue: A Study in a Rat Model of Moderate and Relatively High Human Exposure. Toxicology and Applied Pharmacology, 250, 327-335. http://dx.doi.org/10.1016/j.taap.2010.11.012

[6] Al-Saleh, I. (2000) Selenium Status in Saudi Arabia. Journal of Trace Element and Medical Biology, 14, $154-160$. http://dx.doi.org/10.1016/S0946-672X(00)80004-8

[7] National Research Council (1989) Recommended Dietary Allowances. 10th Edition, National Academy of Sciences, Washington DC, 284-285.

[8] Meotti, F.C., Stangherlin, E., Zeni, G., Nogueira, C.W. and Rocha, J.B.T. (2004) Protective Role of Aryl and Alkyl Diselenide on Lipid Peroxidation. Environmental Research, 94, 276-282.

http://dx.doi.org/10.1016/S0013-9351(03)00114-2

[9] Rao, L.G., Mackinnon, E.S., Josse, R.G., Murray, T.M., Strauss, A. and Rao, A.V. (2007) Lycopene Consumption Decreases Oxidative Stress and Bone Resorption Markers in Postmenopausal Women. Osteoporosis International, 18, 109-115. http://dx.doi.org/10.1007/s00198-006-0205-z

[10] Brzoska, M.M., Rogalska, J., Galazyn-Sidorczuk, M., Jurczuk, M., Roszczenko, A., Kulikowska-Karpinska, E. and Moniuszko-Jakoniuk, J. (2007) Effect of Zinc Supplementation on Bone Metabolism in Male Rats Chronically Exposed to Cadmium. Toxicology, 237, 89-103. http://dx.doi.org/10.1016/j.tox.2007.05.001

[11] Sahin, E. and Gumuslu, S. (2007) Immobilization Stress in Rat Tissues: Alterations in Protein Oxidation, Lipid Peroxidation and Antioxidant Defense System. Comparative Biochemistry and Physiology-Part C: Toxicology \& Pharmacology, 144, 342-347. http://dx.doi.org/10.1016/j.cbpc.2006.10.009

[12] Ben Amara, I., Troudi, A., Soudani, N., Guermazi, F. and Zeghal, N. (2012) Toxicity of Methimazole on Femoral Bone in Suckling Rats: Alleviation by Selenium. Experimental Toxicology and Pathology, 64, 187-195. http://dx.doi.org/10.1016/j.etp.2010.08.005

[13] Kingston, H.M. and Walter, P.J. (1997) The Art and Science of Microwave Sample Preparations for Trace and Ultratrace Elemental Analysis. Wiley-VCH, Hoboken.

[14] Aebi, H. (1984) Catalase in Vitro. Methods in Enzymology, 105, 121-126. http://dx.doi.org/10.1016/S0076-6879(84)05016-3

[15] Kakkar, P., Das, B. and Viswanathan, P.N. (1984) A Modified Spectrophotometric Assay of Superoxide Dismutase. Indian Journal of Biochemistry and Biophysics, 21, 130-132.

[16] Rotruck, J.T., Pope, A.L., Ganther, H.E., Swanson, A.B., Hafeman, D.G. and Hoekstra, W.G. (1973) Selenium: Biochemical Role as a Component of Glutathione Peroxidase. Science, 179, 588-590. http://dx.doi.org/10.1126/science.179.4073.588

[17] Dieber-Rotheneder, M., Puhl, H., Waeg, G., Striegl, G. and Esterbauer, H. (1991) Effect of Oral Supplementation with D-Alpha-Tocopherol on the Vitamin E Content of Human Low Density Lipoproteins and Resistance to Oxidation. 
Journal of Lipid Research, 32, 1325-1332.

[18] Mohanty, J.G., Bhamidipaty, S., Evans, M.K. and Rifkind, J.M. (2010) A Fluorimetric Semi-Microplate Format Assay of Protein Carbonyls in Blood Plasma. Analytical Biochemistry, 400, 289-294. http://dx.doi.org/10.1016/j.ab.2010.01.032

[19] Chen, X., Zhu, G., Jin, T., Gu, S., Tan, M., Xiao, H. and Qiu, J. (2011) Cadmium Exposure Induced Itai-Itai-Like Syndrome in Male Rats. Central European Journal of Medicine, 6, 425-434. http://dx.doi.org/10.2478/s11536-011-0046-9

[20] Messaoudi, I., El-Heni, J., Hammouda, F., Saïd, K. and Kerkeni, A. (2009) Protective Effects of Selenium, Zinc, or Their Combination on Cadmium-Induced Oxidative Stress in Rat Kidney. Biological Trace Elements Research, 130, 152-161. http://dx.doi.org/10.1007/s12011-009-8324-y

[21] Rencuzogullari, N. and Erdogan, S. (2007) Oral Administration of Lycopene Reverses Cadmium-Suppressed Body Weight Loss and Lipid Peroxidation in Rats. Biological Trace Elements Research, 118, 175-183. http://dx.doi.org/10.1007/s12011-007-0027-7

[22] Alhazza, I.M. (2005) Effect of Selenium on Cadmium Induced Gonadotoxicity in Male Rat. Journal of Biological Science, 5, 243-249. http://dx.doi.org/10.3923/jbs.2005.243.249

[23] Turan, B., Can, B. and Delibasi, E. (2003) Selenium Combined with Vitamin E and Vitamin C Restores Structure Alterations of Bones in Heparin-Induced Osteoporosis. Clinical Rheumatology, 22, 432-436. http://dx.doi.org/10.1007/s10067-003-0809-z

[24] Messaoudi, I., Hammouda, F., El-Heni, J., Baati, T., Said, K. and Kerkeni, A. (2010) Reversal of Cadmium-Induced Oxidative Stress in Rat Erythrocytes by Selenium, Zinc or Their Combination. Experimental and Toxicology Pathology, 62, 281-283. http://dx.doi.org/10.1016/j.etp.2009.04.004

[25] El-Heni, J., Messaoudi, I., Hammouda, F. and Kerkeni, A. (2009) Protective Effects of Selenium (Se) and Zinc (Zn) on Cadmium (Cd) Toxicity in the Liver and Kidney of the Rat: Histology and Cd Accumulation. Food and Chemistry Toxicology, 46, 3522-3527.

[26] Ognjanovic, B.I., Markovic, S.D., Pavlovic, S.Z., Zikic, R.V., Stajn, A.S. and Saicic, Z.S. (2008) Effect of Chronic Cadmium Exposure on Antioxidant Defense System in Some Tissues of Rats: Protective Effect of Selenium. Physiological Research, 57, 403-411.

[27] De Haan, J.B., Cristiano, F., Iannello, R., Bladier, C., Kelner, M.J. and Kola, I. (1996) Elevation in the Ratio of Cu/ZnSuperoxide Dismutase to Glutathione Peroxidase Activity Induces Features of Cellular Senescence and This Effect Is Mediated by Hydrogen Peroxide. Human Molecular Genetics, 5, 283-292. http://dx.doi.org/10.1093/hmg/5.2.283

[28] Benzie, I.F.F. (2000) Evolution of Antioxidant Defense Mechanisms. European Journal of Nutrition, 39, 53-61. http://dx.doi.org/10.1007/s003940070030

[29] Saïd, L., Banni, M., Kerkeni, A., Saïd, K. and Messaoudi, I. (2010) Influence of Combined Treatment with Zinc and Selenium on Cadmium Induced Testicular Pathophysiology in Rat. Food and Chemistry Toxicology, 48, 2759-2765. http://dx.doi.org/10.1016/j.fct.2010.07.003

[30] Alvarez, S.M., Gómez, N.N., Scardapane, L., Fornés, M.W. and Gimenéz, M.S. (2007) Effects of Chronic Exposure to Cadmium on Prostate Lipids and Morphology. Biometals, 20, 727-741. http://dx.doi.org/10.1007/s10534-006-9036-9

[31] Nogawa, K., Tsuritani, I., Kido, T., Honda, R., Yamada, Y. and Ishizaki, M. (1987) Mechanism for Bone Disease Found in Inhabitants Environmentally Exposed to Cadmium: Decreased Serum 1 Alpha, 25-Dihydroxyvitamin D Level. International Archive of Occupational and Environmental Health, 59, 21-30. http://dx.doi.org/10.1007/BF00377675

[32] Thijssen, S., Maringwa, J., Faes, C., Lambrichts, I. and Van Kerkhove, E. (2007) Chronic Exposure of Mice to Environmentally Relevant, Low Doses of Cadmium Leads to Early Renal Damage, Not Predicted by Blood or Urine Cadmium Levels. Toxicology, 229, 145-156. http://dx.doi.org/10.1016/j.tox.2006.10.011

[33] Jihen, H., Imed, M., Fatima, H. and Abdelhamid, K. (2008) Protective Effects of Selenium (Se) and Zinc (Zn) on Cadmium (Cd) Toxicity in the Liver and Kidney of the Rat: Histology and Cd Accumulation. Food and Chemistry Toxicology, 46, 3522-3527. http://dx.doi.org/10.1016/j.fct.2008.08.037

[34] Crissman, J.W., Goodman, D.G., Hildebrandt, P.K., Maronpot, R.R., Prater, D.A., Riley, J.H., Seaman, W.J. and Thake, D.C. (2004) Best Practices Guideline: Toxicologic Histopathology. Toxicologic Pathology, 32, 126-131. http://dx.doi.org/10.1080/01926230490268756

[35] Yousef, I.M., El-Demerdash, M.M. and Radwan, F.M.E. (2008) Sodium Arsenite Induced Biochemical Perturbations in Rats: Ameliorating Effect of Curcumin. Food and Chemical Toxicology, 46, 3506-3511. http://dx.doi.org/10.1016/j.fct.2008.08.031

[36] El-Demerdash, F.M., Yousef, M.I., Kedwany, F.S. and Baghdadi, H.H. (2004) Cadmium-Induced Changes in Lipid 
Peroxidation, Blood Hematology, Biochemical Parameters and Semen Quality of Male Rats: Protective Role of Vitamin E and Beta-Carotene. Food and Chemistry Toxicology, 42, 1563-1571.

http://dx.doi.org/10.1016/j.fct.2004.05.001

[37] Gupta, R.S., Gupta, E.S., Dhakal, B.K., Thakur, A.R. and Ahnn, J. (2004) Vitamin C and Vitamin E Protect the Rat Testes from Cadmium-Induced Reactive Oxygen Species. Molecular and Cells, 17, 132-139.

[38] Waisberg, M., Joseph, P., Hale, B. and Beyersmann, D. (2003) Molecular and Celluar Mechanisms of Cadmium Carcinogenesis. Toxicology, 192, 95-117. http://dx.doi.org/10.1016/S0300-483X(03)00305-6

[39] Brzóska, M.M. and Moniuszko-Jakoniuk, J. (2005) Disorders in Bone Metabolism of Female Rats Chronically Exposed to Cadmium. Toxicology and Applied Pharmacology, 202, 68-83. http://dx.doi.org/10.1016/j.taap.2004.06.007

[40] Ogoshi, K., Moriyama, T. and Nanzai, Y. (1989) Decrease in the Mechanical Strength of Bones of Rats Administered Cadmium. Archive of Toxicology, 63, 320-324. http://dx.doi.org/10.1007/BF00278646

[41] Hunder, G., Javdani, J., Elsenhans, B. and Schümann, K. (2001) ${ }^{109} \mathrm{Cd}$ Accumulation in the Calcified Parts of Rat Bones. Toxicology, 159, 1-10. http://dx.doi.org/10.1016/S0300-483X(00)00364-4

[42] David, S.S., O’Shea, V.L. and Kundu, S. (2007) Base-Excision Repair of Oxidative DNA Damage. Nature, 447, 941950. http://dx.doi.org/10.1038/nature05978

[43] Gong, Q. and Hart, B.A. (1997) Effect of Thiols on Cadmium-Induced Expression of Metallothionein and Other Oxidant Stress Genes in Rat Lung Epithelial Cells. Toxicology, 119, 179-191. http://dx.doi.org/10.1016/S0300-483X(96)03608-6

[44] Sabolić, I., Breljak, D., Škarica, M. and Herak-Kramberger, C.M. (2010) Role of Metallothionein in Cadmium Traffic and Toxicity in Kidneys and Other Mammalian Organs. Biometals, 23, 897-926. http://dx.doi.org/10.1007/s10534-010-9351-z

[45] Valko, M., Rhodes, C.J., Moncol, J., Izakovic, M. and Mazur, M. (2006) Free Radicals, Metals and Antioxidants in Oxidative Stress-Induced Cancer. Chemical-Biological Interactions, 160, 1-40. http://dx.doi.org/10.1016/j.cbi.2005.12.009

[46] Quig, D. (1998) Cysteine Metabolism and Metal Toxicity. Alternative Medicine Review, 3, 262-270.

[47] Casalino, E., Calzaretti, G., Sblano, C. and Landriscina, C. (2002) Molecular Inhibitory Mechanisms of Antioxidant Enzymes in Rat Liver and Kidney by Cadmium. Toxicology, 179, 37-50. http://dx.doi.org/10.1016/S0300-483X(02)00245-7

[48] Sies, H. (1993) Strategies of Antioxidant Defense. European Journal of Biochemistry, 215, 213-219. http://dx.doi.org/10.1111/j.1432-1033.1993.tb18025.x

[49] Hussain, T., Shukla, G.S. and Chandra, S.V. (1987) Effects of Cadmium on Superoxide Dismutase and Lipid Peroxidation in Liver and Kidney of Growing Rats: In Vivo and in Vitro Studies. Pharmacology and Toxicology, 60, 355-358. http://dx.doi.org/10.1111/j.1600-0773.1987.tb01526.x

[50] Ohta, H., Seki, Y. and Yoshikawa, H. (1995) Interactive Effects of Selenium on Chronic Cadmium Toxicity in Rats. Archives of Complex Environmental Studies, 8, 97-104.

[51] Gan, L., Liu, Q., Xu, H.B., Zhu, Y.S. and Yang, X.L. (2002) Effects of Selenium Overexposure on Glutathione Peroxidase and Thioredoxin Reductase Gene Expressions and Activities. Biological Trace Elements Research, 89, 165175. http://dx.doi.org/10.1385/BTER:89:2:165

[52] Singh, K., Bal, B., Chopra, S., Singh, S. and Malhotra, N. (2012) Ameliorative Effect of Lycopene on Lipid Peroxidation and Certain Antioxidant Enzymes in Diabetic Patients. Journal of Diabetes and Metabolism, 3, 1000-1100. 
Scientific Research Publishing (SCIRP) is one of the largest Open Access journal publishers. It is currently publishing more than 200 open access, online, peer-reviewed journals covering a wide range of academic disciplines. SCIRP serves the worldwide academic communities and contributes to the progress and application of science with its publication.

Other selected journals from SCIRP are listed as below. Submit your manuscript to us via either submit@scirp.org or Online Submission Portal.
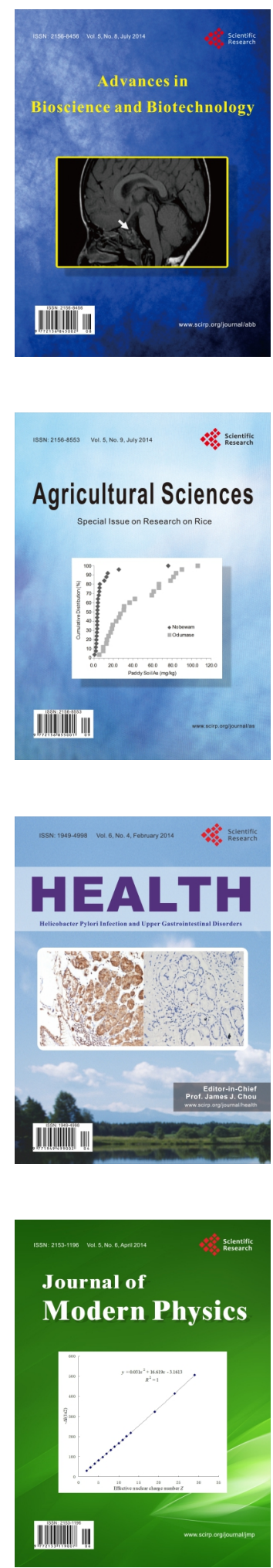
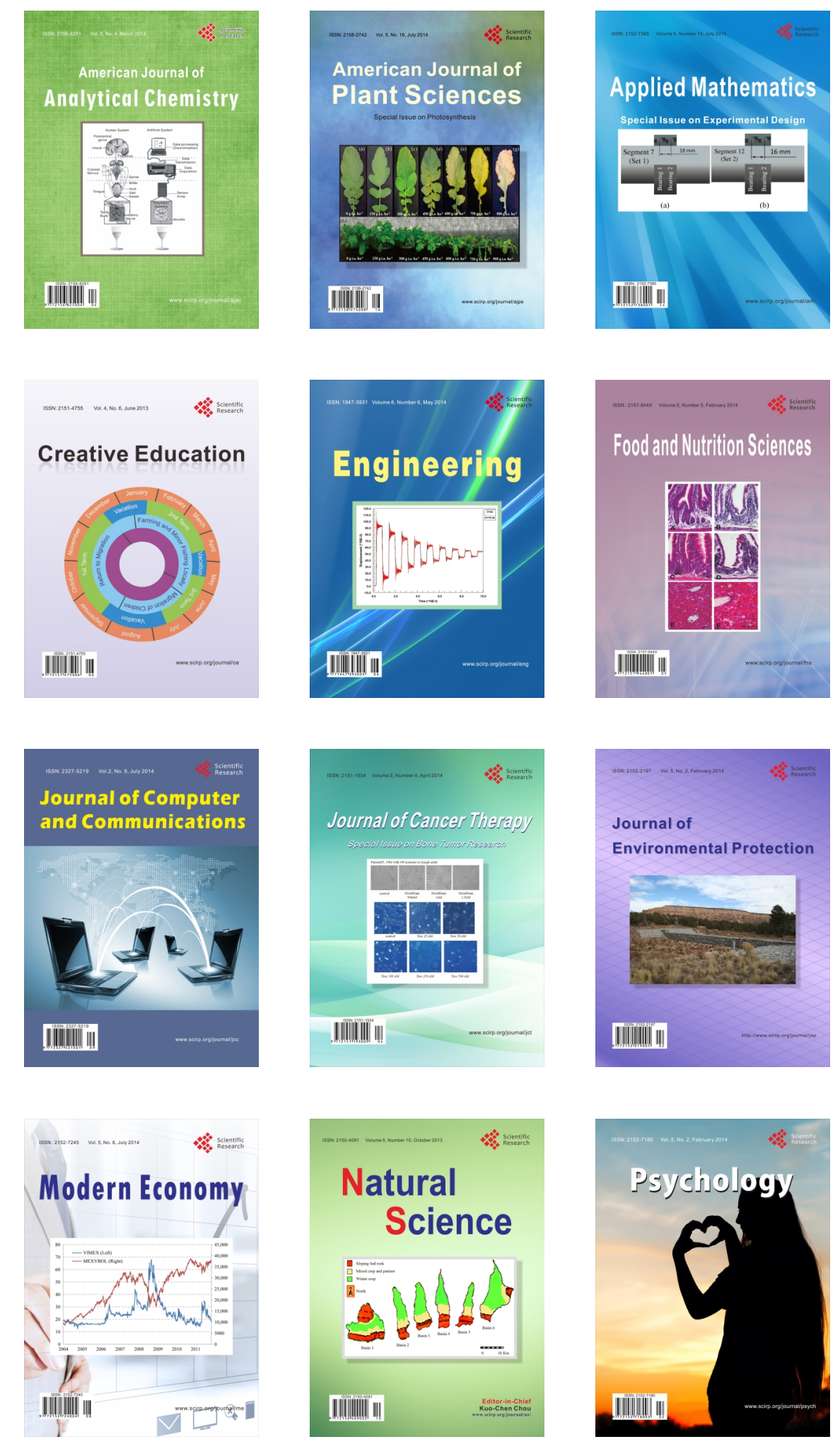